\title{
HUBUNGAN CAPAIAN PEMBELAJARAN TEORI SIMULASI DIGITAL TERHADAP KINERJA SISWA DALAM PRAKTIKUM SIMULASI DIGITAL PADA KOMPETENSI KEAHLIAN TEKNIK AUDIO VIDEO KELAS X DI SMK NEGERI 3 SINGARAJA
}

\author{
Putri Nugrahaning Dyah Utami'1), I Putu Suka Arsa ${ }^{2}$, I Gede Nurhayata ${ }^{3)}$ \\ ${ }^{1}$ Fakultas Teknik dan Kejuruan, Universitas Pendidikan Ganesha (penulis 1) \\ Email: dyah.putri47@ymail.com \\ ${ }^{2}$ Fakultas Teknik dan Kejuruan, Universitas Pendidikan Ganesha (penulis 2) \\ Email: suka.arsa@undiksha.ac.id \\ ${ }^{3}$ Fakultas Teknik dan Kejuruan, Universitas Pendidikan Ganesha (penulis 2) \\ Email: gede.nurhayata@undiksha.ac.id
}

\begin{abstract}
ABSTRAK
Penelitian ini bertujuan untuk mengetahui (1) hubungan antara capaian pembelajaran teori simulasi digital dengan kinerja siswa dalam praktikum simulasi digital program keahlian Teknik Audio Video kelas X di SMK Negeri 3 Singaraja, (2) tinggi tingkat capaian pembelajaran teori simulasi digital program keahlian Teknik Audio Video kelas X di SMK Negeri 3 Singaraja, dan (3) tinggi kinerja siswa saat praktikum simulasi digital program keahlian Teknik Audio Video kelas X di SMK Negeri 3 Singaraja. Penelitian ini adalah penelitian korelasional. Penelitian ini dilakukan di sekolah SMK Negeri 3 Singaraja program keahlian Teknik Audio Video kelas X tahun ajaran 2016/2017. Sampel yang diteliti adalah siswa kelas X Teknik Audio Video ${ }^{1}$ dengan jumlah sampel sebanyak 30 siswa. Variabel yang diteliti adalah dua variabel, satu variabel bebas, yaitu capaian pembelajaran dan satu variabel terikat, yaitu kinerja siswa. Data capaian pembelajaran diperoleh melalui penyebaran tes, sedangkan kinerja siswa di peroleh dari lembar pengamatan, serta untuk mendapatkan penjelasan mengenai hubungan yang diberikan antar variabel penelitian dilakukan dengan menggunakan analisa teknik uji spearman rank dengan terlebih dahulu melakukan uji asumsi, yaitu uji normalitas, uji linieritas, dan uji heterokedastisitas. Hasil penelitian menunjukkan terdapat hubungan antara capaian pembelajaran teori simulasi digital terhadap kinerja siswa dalam praktikum simulasi digital program keahlian Teknik Audio Video kelas X di SMK Negeri 3 Singaraja, dengan koefisien korelasi $R$ sebesar $0,565>0,05$ dan nilai probabilitas sebesar 0,001<0,05 dengan tingkat korelasi cukup kuat. Pada pencapaian pembelajaran teori simulasi digital dalam pokok bahasan presentasi video diperoleh rata-rata kelas sebesar $82 \%$ dengan kategori baik, dan tingkat kinerja siswa saat praktikum diperoleh rata-rata kelas sebesar $89 \%$ dengan kategori baik.
\end{abstract}

Kata kunci: Capaian Pembelajaran, Kinerja Siswa, Simulasi Digital

\begin{abstract}
This study aimed to determine (1) the correlation between learning achievement of digital simulation theory on students' performance in digital simulation practice of Audio Video Engineering program at tenth grade students in SMK Negeri 3 Singaraja, (2) the level of learning achievement of digital simulation theory of Audio Video Engineering program at tenth grade students in SMK Negeri 3 Singaraja, and (3) the level of student performance during the digital simulation practicum of Audio Video Engineering program at tenth grade students in SMK Negeri 3 Singaraja. This study was Correlational Study. This study was conducted in SMK Negeri 3 Singaraja at tenth grade of Audio Video Engineering Program in academic year 2016/2017. Sample of this study was the tenth grade students of Audio Video Engineering Program and total of the sample was 30 students. There were two variables in this study, namely learning achievement as the independent variable and students' performance as the dependent variable. The learning achievement data were obtained through administering the test, while the students' performance was obtained through observation sheet. Spearman rank test technique analysis was used to obtain an explanation about the correlation between the variables in which the assumption tests were done first, namely normality test, linearity test, and heteroscedasticity test. The result of the study showed that there was a correlation between learning achievement of digital simulation theory on students' performance in digital simulation practice of Audio Video Engineering program at tenth grade students in SMK Negeri 3 Singaraja, in which the correlation coefficient $R$ was $0.565>0.05$ and the probability value was $0.001<0.05$ and the correlation rate was strong enough. On the learning achievement of digital simulation theory in the video presentation subject, it was found that the mean score of the class was $82 \%$ with good category, and the mean score of the class on the students' performance level during practicum was $89 \%$ with good category.
\end{abstract}

Keywords: Learning Achievement, Students' Performance, Digital Simulation 


\section{PENDAHULUAN}

Hasil belajar adalah kemampuankemampuan yang dimiliki siswa setelah ia menerima pengalaman belajar. Ada tiga ranah atau domain besar yang selanjutnya disebut dengan taksonomi, yaitu ranah kognitif (cognitive domain), ranah afektif (affective domain), dan ranah psikomotor (psychomotor domain). Kemampuan intelektual siswa menjadi tolak ukur keberhasilan dalam proses pembelajaran pada ranah kognitif. Ketercapaian masingmasing indikator pada setiap ranah hasil belajar tersebut menunjukkan keberhasilan pencapaian hasil belajar siswa pada setiap ranah hasil belajar. Salah satu ranah hasil belajar yang menjadi orientasi utama di sekolah pada umumnya adalah ranah kognitif. Fokus pada ranah kognitif terlihat pada penekanan hasil ujian akhir baik semester maupun nasional. Pencapaian hasil belajar pada ranah tersebut kemudian menjadi lebih menonjol dibandingkan dengan ranah yang lain.

Faktor-faktor yang mempengaruhi atau menentukan keberhasilan belajar itu banyak. Ada kalanya juga individu yang satu memerlukan faktor yang berbeda daripada individu lain di dalam mencapai keberhasilan belajar. Secara garis besar, faktor-faktor yang mempengaruhi keberhasilan belajar itu dapat kira bagi menjadi dua bagian, yaitu faktor internal dan faktor eksternal. Faktor internal adalah faktor yang terdapat di dalam diri individu itu sendiri, seperti kesehatan jasmani dan rohani, kecerdasan (intelegensia), daya ingat, kemauan, dan bakat. Faktor eksternal adalah faktor yang terdapat di luar individu yang bersangkutan, seperti keadaan rumah, sekolah, masyarakat, dan segala sesuatu yang berhubungan dengan semua lingkungan tersebut. Demikianlah kiranya beberapa faktor internal dan eksternal yang sangat perlu diperhatikan mengingat faktor-faktor tersebut sangat berpengaruh dan menentukan keberhasilan belajar seseorang. Faktor internal itu diketahui lebih dominan dalam menentukan hasil belajar terutama yang bersifat psikologis seringkali lebih sulit diatasi daripada kesulitan belajar yang bersumber pada faktor-faktor eksternal.

SMK Negeri 3 Singaraja adalah salah satu sekolah kejuruan bidang teknologi dan industri yang beralamat di Jalan Gempol, Banyuning, Kec. Buleleng, Kabupaten Buleleng. Sekolah ini berdiri pada tahun 1980 tepatnya pada tanggal 1 Juli 1980, kemudian pada tanggal 10 Januari 1981 STM Nasional Singaraja diresmikan menjadi sekolah negeri dan berganti nama menjadi STM Negeri Singaraja. Dengan SK yang dikeluarkan oleh Kanwil Depdikbuk Provinsi Bali bernomor 54585/c/2/1981 tertanggal 1 Juli 1981. SMK Negeri 3 Singaraja ini membuka berbagai bidang keahlian dan setidaknya sudah dibuka 10 bidang keahlian, yaitu kompetensi keahlian teknik komputer jaringan, multimedia, teknik audio video, teknik instalasi tenaga listrik, teknik kendaraan ringan, teknik sepeda motor, teknik pemesinan, teknik pengelasan, teknik gambar bangunan, dan teknik konstruksi bangunan. Sekolah ini menerapkan sistem pembelajaran blok dimana satu minggu siswa mempelajari pembelajaran teori dan satu minggu praktikum. Teknik audio video adalah salah satu kompetensi keahlian yang mempelajari tentang rekaman audio studio, rekaman video, memperbaiki penerima televisi, memperbaiki alat reproduksi sinyal audio dan lain-lain. Pada kompetensi keahlian teknik audio video ini ada beberapa ruangan, yaitu ruang untuk editing, ruang kelas, ruang rekaman, dan ruang bengkel elektronika.

Penggunaan metode dalam kegiatan pembelajaran sangat perlu karena untuk mempermudah proses pembelajaran sehingga dapat mencapai hasil yang optimal. Tanpa adanya metode yang jelas, maka proses pembelajaran tidak akan terarah sehingga tujuan pembelajaran yang telah ditetapkan sulit tercapai seperti optimal. Metode sangat berguna bagi guru dan siswa, bagi guru metode dapat dijadikan pedoman dan acuan bertindak yang sistematis dalam pelaksanaan pembelajaran, dan bagi siswa dapat mempermudah proses belajar serta siswa lebih mudah untuk menyerap materi yang di ajarkan oleh guru dan tetap tertanam di 
siswa maka metode praktiklah yang sesuai karena setelah siswa mendapatkan pembelajaran teori kemudian siswa langsung dapat mempraktikkan nya.

SMK Negeri 3 Singaraja adalah salah satu sekolah kejuruan teknik yang menggunakan metode pembelajaran teori dan praktik. Disini guru memberikan penjelasan materi praktik terlebih dahulu kepada siswanya agar dapat menarik perhatian siswa, beberapa materi pembelajaran praktik dapat disajikan melalui media audio visual, setelah guru memberikan pengetahuan materi praktik guru mendemonstrasikan atau menunjukkan langkah praktik yang benar kepada siswa dengan menggunakan peragaan, dan kemudian siswa dapat langsung mempraktikannya dengan tugas yang diberikan dengan tujuan untuk mengembangkan dan mendemostrasikan keterampilan. Kegiatan praktik memungkinkan siswa untuk lebih efektif terlibat dalam kegiatan belajar, hal-hal yang telah dipelajari saat diberikan pembelajaran teori oleh guru dapat diimplementasikan pada saat praktik. Capaian pembelajaran teori yang didapatkan siswa itu rata-rata kurang atau bisa dibilang masih banyak yang mendapatkan nilai dibawah nilai ratarata sekolah, sedangkan pada saat praktikum siswa itu lebih aktif dibandingkan saat pembelajaran teori dimana siswa itu tidak terlalu fokus pada pembelajaran teori yang mengakibatkan capaian pembelajaran teori yang didapatkan lebih kecil dibandingkan dengan praktikum. Seperti kenyataan yang ada, beberapa siswa ada yang ahli saat pembelajaran teori tapi tidak dalam praktikum, ada pula yang ahli dalam praktikum tetapi saat pembelajaran teori kurang, ada pula siswa yang saat pembelajaran teori dan praktikum dapat dia pahami.

Berdasarkan hal tersebut seseorang yang rendah dalam salah satu komponenya maka kinerjanya akan rendah pula, dengan demikian dapat pula diartikan bahwa seseorang yang kinerjanya rendah maka hal tersebut dapat merupakan hasil dari motivasinya yang rendah atau kemampuannya yang kurang atau keduaduanya, yaitu motivasi dan kemampuannya yang rendah. Meskipun seseorang mempunyai kemampuan dan kemauan, tapi mungkin saja ada penghalang yang bisa menghambat. Penghalang tersebut bisa datang dari dalam diri seseorang itu sendiri maupun dari luar diri, seperti keluarga dan lingkungan.

Seharusnya siswa saat sekolah dapat fokus pada materi pembelajaran saat teori, agar pada saat praktikum siswa dapat mengimplementasikan pengetahuanpengetahuan teori yang didapat. Bisa saja beberapa siswa ada yang kurang dalam kemampuannya di saat pembelajaran teori tetapi dia mampu saat pembelajaran praktikum, ada pula siswa yang kurang dalam praktikum tetapi mampu dalam pembelajaran teori, ada pula siswa yang mampu dalam kedua komponen tersebut, baik teori maupun praktek. Maka berdasarkan hal tersebut peneliti tertarik untuk melakukan penelitian tentang hubungan antara capaian pembelajaran teori dengan kinerja siswa dalam paktikum. Oleh karena itu, peneliti mengambil judul "Hubungan antara Capaian Pembelajaran Teori Simulasi Digital terhadap Kinerja Siswa dalam Praktikum Simulasi Digital pada Kompetensi Keahlian Teknik Audio Video Kelas X di SMK Negeri 3 Singaraja".

Bertitik tolak dari latar belakang diatas, maka perlu dirumuskan permasalahan permasalahan dalam penelitian ini adalah apakah terdapat hubungan antara capaian pembelajaran teori simulasi digital terhadap kinerja siswa dalam praktikum simulasi digital di SMK Negeri 3 Singaraja pada Kompetensi Keahlian Teknik Audio Video Kelas $X$ ?, berapakah tingkat pencapaian pembelajaran teori simulasi digital program keahlian Teknik Audio Video kelas X di SMK Negeri 3 Singaraja?, berapakah tingkat kinerja siswa saat praktikum simulasi digital pada program keahlian Teknik Auido Video kelas X di SMK Negeri 3 Singaraja?

Sesuai dengan permasalahan yang dijabarkan pada rumusan masalah diatas, adapun tujuan dari diadakan penelitian ini untuk mengetahui hubungan antara capaian pembelajaran teori simulasi digital terhadap kinerja dalam praktikum simulasi digital di SMK Negeri 3 Singaraja pada Kompetensi Keahlian Teknik Audio Video Kelas X, untuk mengetahui tingkat pencapaian pembelajaran teori simulasi digital program 
keahlian Teknik Audio Video kelas X di SMK Negeri 3 Singaraja, untuk mengetahui tingkat kinerja siswa saat praktikum simulasi digital program keahlian Teknik Audio Video kelas X di SMK Negeri 3 Singaraja.

Agar masalah dalam penelitian ini lebih fokus dan tidak menyimpang dari apa yang ingin diteliti, maka peneliti membatasi penelitian ini pada permasalahan sebagai berikut:

1. Mata pelajaran yang diteliti adalah simulasi digital dalam pokok bahasan presentasi video.

2. Populasi dalam penelitian ini adalah siswa kelas $\mathrm{X}$ program keahlian Teknik Audio Video di SMK Negeri 3 Singaraja.

3. Sampel dalam penelitian ini adalah siswa kelas $X$ TAV $^{1}$ di SMK Negeri 3 Singaraja.

4. Variabel bebas dalam penelitian ini adalah capaian pembelajaran teori. Capaian pembelajaran teori diukur dengan melaksanakan post test.

5. Variabel terikat dalam penelitian ini adalah kinerja siswa dalam praktikum. Kinerja siswa ini ukur dengan menggunakan lembar pengamatan kinerja siswa saat praktikum.

6. Program yang digunakan untuk analisis data dan uji hipotesis menggunakan SPSS versi 22.

\section{Capaian Pembelajaran}

Capaian pembelajaran (learning outcomes) adalah suatu ungkapan tujuan pendidikan, yang merupakan suatu pernyataan tentang apa yang diharapkan diketahui, dipahami, dan dapat dikerjakan oleh siswa setelah menyelesaikan suatu periode belajar. Capaian pembelajaran adalah kemampuan yang diperoleh melalui internalisasi pengetahuan, sikap, keterampilan, kompetensi, dan akumulasi pengalaman kerja.

Istilah capaian pembelajaran kerapkali digunakan dengan kompetensi, meskipun memiliki pengertian yang berbeda dari segi ruang lingkup pendekatannya. Allan (dalam RISTEKDIKSI,2015) menjelaskan bahwa banyak terminologi digunakan untuk menjelaskan educational intent, di antaranya adalah: learning outcomes, teaching objectives, competencies, behavioral objectives, goals dan aims.
Menurut RISTEKDIKTI,2015) "alms" merupakan ungkapan tujuan pendidikan yang bersifat luas dan umum, yang menjelaskan informasi kepada siswa tentang tujuan suatu pelajaran, program atau modul dan umumnya ditulis untuk pengajar bukan untuk siswa. Sebaliknya capaian pembelajaran (learning outcomes) lebih difokuskan pada apa yang diharapkan dapat dilakukan oleh siswa selama atau pada akhir suatu proses belajar. Sedangkan "abjectives" cakupannya meliputi belajar dan mengajar dan kerapkali digunakan dalam proses assesmen.

Capaian pembelajaran menunjukkan kemajuan belajar yang digambarkan secara vertikal dari satu tingkat ke tingkat yang lain serta didokumentasikan dalam suatu kerangka kualifikasi. Capaian pembelajaran harus disertai dengan kriteria penilaian yang tepat yang dapat digunakan untuk menilai bahwa hasil pembelajaran yang diharapkan telah tercapai.

\section{Kinerja}

Menurut Mangkunegara Anwar Prabu (dalam Diman, 2012), kinerja diartikan sebagai "Hasil kerja secara kualitas dan kuantitas yang dicapai oleh seseorang dalam melaksanakan tugasnya sesuai dengan tanggung jawab yang diberikan kepadanya." Sedangkan menurut Wirawan yang dimaksud dengan kinerja adalah "Keluaran yang dihasilkan oleh fungsi-fungsi suatu pekerjaan atau suatu profesi dalam waktu tertentu. Oleh karena itu definisi kinerja yang dapat disimpulkan bahwa sependapat dari Mangkunegara Anwar Prabu, merupakan suatu hasil kinerja secara kualitas yang dicapai oleh seseorang dalam melaksanakan tugasnya sesuai dengan tanggung jawab yang diberikan kepadanya.

$$
\text { Menurut Setyono (2005:3) }
$$

performance assessment adalah penilaian berdasarkan hasil pengamatan penilai terhadap aktivitas siswa sebagaimana yang terjadi. Penilaian dilakukan terhadap unjuk kerja, tingkah laku, atau interaksi siswa. Performance assessment digunakan untuk menilai kemampuan siswa melalui penugasan. Penugasan tersebut dirancang khusus untuk menghasilkan respon (lisan atau tulis), menghasilkan karya (produk), atau menunjukkan penerapan pengetahuan. 
Tugas yang diberikan kepada siswa harus sesuai dengan kompetensi yang ingin dicapai dan bermakna bagi siswa.

Sedangkan menurut Majid (2006:88), performance assessment merupakan penilaian dengan berbagai macam tugas dan situasi di mana peserta tes diminta untuk mendemonstrasikan pemahaman dan pengaplikasian pengetahuan yang mendalam, serta keterampilan di dalam berbagai macam konteks. Jadi boleh dikatakan bahwa performance assessment adalah suatu bentuk penilaian untuk mendemonstrasikan atau mengaplikasikan pengetahuan yang telah diperoleh oleh siswa dan menggambarkan suatu kemampuan siswa melalui suatu proses, kegiatan atau unjuk kerja.

\section{METODE PENELITIAN \\ Rancangan Penelitian}

Jenis penelitian ini adalah penelitian korelasional, yaitu penelitian yang berusaha untuk menentukan ada tidaknya hubungan (asosiasi) antara dua variabel atau lebih dan tingkat hubungan antara dua variabel atau lebih tanpa ada upaya untuk mempengaruhi variabel tersebut sehingga tidak terdapat manipulasi variabel. Yang perlu diperhatikan pada penelitian korelasional adalah penelitian korelasi tidak dapat menjelaskan sebabakibat, melainkan hanya menjelaskan ada tidaknya hubungan antarvariabel.

\section{Populasi dan Sampel Penelitian}

Populasi dalam penelitian ini adalah seluruh siswa kelas $X$ program keahlian Teknik Audio Video tahun ajaran 2016/2017 yang berjumlah 60 siswa, dengan rincian kelas $\mathrm{X} \mathrm{TAV}^{1}$ dengan jumlah 30 siswa dan $\mathrm{X}$ $\mathrm{TAV}^{2}$ berjumlah 30 siswa, sedangkan sampel pada penelitian ini adalah siswasiswi kelas $X$ Teknik Audio Video ${ }^{1}$ tahun ajaran 2016/2017 yang berjumlah 30 siswa.

\section{Metode Pengumpulan Data}

Metode pengumpulan data yang digunakan dalam penelitian ini adalah tes, dan lembar pengamatan kinerja siswa. Dimana terlebih dahulu instrumen tes (post test) di uji validitas isi oleh 2 orang ahli.
Setelah itu, instrumen tersebut diujicobakan pada sampel dari mana populasi diambil. Jumlah anggota sampel yang digunakan sebanyak 30 siswa. Kemudian instrumen diujicobakan kepada responden selanjutnya dihitung dengan teknik korelasi product moment adalah sebagai berikut.

$$
r_{x y}=\frac{N \sum X Y-\left(\sum X\right)\left(\sum Y\right)}{\sqrt{\left\{N \sum X^{2}-\left(\sum X\right)^{2}\right\}\left\{N \sum Y^{2}-\left(\sum Y\right)^{2}\right\}}}
$$

Keterangan:

$R_{x y}=$ Koefisien korelasi antara $X$ dan $Y$

$\mathrm{N}$ = Jumlah objek uji coba

$\mathrm{X}$ = Skor yang diperoleh siswa pada butir yang akan diuji validitasnya

$Y=$ Skor total yang diperoleh

$\sum X^{2}=$ Jumlah kuadrat nilai $X$

$\sum Y^{2}=$ Jumlah kuadrat nilai $Y$

\section{Teknik Analisis Data}

Teknik analisis data yang digunakan dalam penelitian adalah teknik analisis data statistik deskriptif dan uji prasyarat atau uji asumsi. Uji prasyarat yang dilakukan dalam penelitian ini bertujuan untuk membuktikan bahwa data yang dikumpulkan layak untuk dianalisis dengan statistik parametrik atau non parametrik. Uji prasyarat yang dilakukan adalah uji normalitas sebaran data dilakukan untuk menyajikan bahwa sampel benarbenar berasal dari populasi yang berdistribusi normal, uji linieritas arah regresi dilakukan untuk mengetahui hubungan antara variabel terikat dengan variabel bebas, dan uji heterokedastisitas.

\section{HASIL PENELITIAN DAN PEMBAHASAN Hasil}

Untuk mendapatkan gambaran mengenai karakteristik distribusi skor dari masing-masing variabel, berikut disajikan hasil analisis deskriptif data capaian pembelajaran menunjukkan bahwa skor rata-rata adalah sebesar 32.07, skor minimum sebesar 26, skor maksimum sebesar 35, sedangkan hasil analisis deskriptif dari kinerja siswa menunjukkan bahwa skor rata-rata adalah 64.03, skor minimum sebesar 58, dan skor maksimum sebesar 69. Rangkuman statistik deskriptif disajikan pada Tabel 1.

\section{Tabel 1. Rangkuman Statistik Deskriptif Variabel Capaian Pembelajaran (X) terhadap Kinerja Siswa (Y)}




\begin{tabular}{|l|c|c|}
\hline Variabel / Statistik & Capaian Pembelajaran & Kinerja Siswa \\
\hline $\mathrm{N}$ & 30 & 30 \\
\hline Mean & 32.07 & 64.03 \\
\hline Median & 32 & 64 \\
\hline Std & 2.196 & 2.798 \\
\hline Varian & 4.283 & 7.826 \\
\hline Minimum & 26 & 58 \\
\hline Maksimum & 35 & 69 \\
\hline
\end{tabular}

Hasil konversi skor capaian pembelajaran menunjukkan bahwa siswa dengan predikat sabngat baik sebanyak 28 orang (93\%), predikat baik sebanyak 2 orang $(7 \%)$, sedangkan tidak ada responden yang termasuk dalam predikat cukup baik, kurang baik, dan sangat kurang baik. Jadi, sebagian besar siswa kelas $\mathrm{X} \mathrm{TAV}^{1}$ memiliki predikat tes kognitif sangat baik dengan presentase sebesar 93\%. Rangkuman konversi skor capaian pembelajaran dapat dilihat pada Tabel 2.

Tabel 2. Konversi Skor Capaian Pembelajaran

\begin{tabular}{|c|c|c|l|}
\hline Interval & Frekuensi & Presentase & \multicolumn{1}{|c|}{ Predikat } \\
\hline $29.25-39$ & 28 & $93 \%$ & Sangat Baik \\
\hline $22.75-29.24$ & 2 & $7 \%$ & Baik \\
\hline $16.25-22.74$ & 0 & $0 \%$ & Cukup Baik \\
\hline $9.75-16.24$ & 0 & $0 \%$ & Kurang Baik \\
\hline$\leq 9,74$ & 0 & $0 \%$ & Sangat Kurang Baik \\
\hline Jumlah & 30 & $100 \%$ & \multicolumn{1}{|c}{} \\
\cline { 1 - 2 } & \multicolumn{3}{|l}{}
\end{tabular}

Hasil konversi skor kinerja siswa menunjukkan bahwa siswa dengan predikat sangat baik sebanyak 29 orang (97\%), predikat baik sebanyak 1 siswa (3\%), sedangkan tidak ada responden yang termasuk dalam predikat cukup baik, kurang baik, dan sangat kurang baik. Jadi, sebagaian besar siswa $\mathrm{TAV}^{1}$ ada pada predikat sangat baik dengan frekuensi sebanyak 29 orang (97\%). Rangkuman skor kinerja siswa disajikan pada Tabel 3.

Tabel 3. Konversi Skor Kinerja Siswa

\begin{tabular}{|c|c|c|l|}
\hline Interval & Frekuensi & Presentase & \multicolumn{1}{|c|}{ Predikat } \\
\hline $58.5-72$ & 29 & $97 \%$ & Sangat Baik \\
\hline $49.5-58.4$ & 1 & $3 \%$ & Baik \\
\hline $40.5-49.4$ & 0 & $0 \%$ & Cukup Baik \\
\hline $31.5-40.4$ & 0 & $0 \%$ & Kurang Baik \\
\hline$\leq 31.4$ & 0 & $0 \%$ & Sangat Kurang Baik \\
\hline Jumlah & 30 & $100 \%$ & \multicolumn{1}{|c}{} \\
\cline { 1 - 3 } & \multicolumn{3}{|c|}{}
\end{tabular}

Sebelum uji hipotesis dilakukan, terlebih dahulu dilakukan uji prasayarat analisis yang lazim disebut dengan uji asumsi. Terdapat tiga uji prasyarat yang dilakukan, yaitu uji normalitas sebaran data, uji linieritas arah regresi, dan uji heterokedastisitas. Setelah dilakukan uji prasyarat analisis menunjukkan data capaian pembelajaran tidak normal, data kinerja sisiwa berdistribusi normal, hubungan capaian pembelajaran dan kinerja siswa mempunyai hubungan yang linier serta koefisien arah regresi berarti, data bebas dari gejala heteroskedastisitas sehingga uji hipotesis bisa dilanjutkan. 
Merujuk dari uji prasyarat analisis tersebut, uji hipotesis menggunakan spearman rank.

Pengujian normalitas sebaran data dilakukan dengan menggunakan uji Shapiro Wilk yang dikenakan terhadap skor capaian pembelajaran dan kinerja siswa. Rekapitulasi hasil pengujian normalitas sebaran data dengan uji Shapiro Wilk pada taraf signifikansi $\alpha=0,05$ dengan hasil $X$ sebesar $0,001<0,05$ dan $Y$ sebesar $0,225>0,05$. Ini berarti skor capaian pembelajaran berdistribusi tidak normal dan skor kinerja siswa berdistribusi normal.

Uji linieritas garis regresi untuk memprediksi atau menguji pengaruh satu variabel bebas terhadap variabel terikat. Analisis regresi juga dapat dilakukan untuk mengetahui linieritas variabel terikat dengan variabel bebas. Pengujian linieritas dilakukan dengan menggunakan uji $F$. Dari hasil uji $F$ terlihat bahwa $F$ hitung sebesar 5,824 dengan tingkat signifikansi sebesar $0,023<0,05$, maka model regresi dapat dipakai untuk memprediksikan variabel terikat.

Uji yang digunakan untuk mengetahui heterokedastisitas adalah dengan menggunakan model regression linier. Berdasarkan uji heterokedastisitas dengan menggunakan metode uji glejser diperoleh nilai signifikansi sebesar 0,263>0,05, sehingga dapat disimpulkan bahwa data tidak terjadi heterokedastisitas.
Setelah uji prasyarat terpenuhi maka akan dilanjutkan dengan uji hipotesis untuk menjawab permasalah penelitian. Hipotesis yang diuji dalam penelitian ini adalah hubungan antara pencapaian pembelajaran teori simulasi digital dengan kinerja siswa dalam praktikum simulasi digital pada program keahlian Teknik Audio Video kelas $X$ di SMK Negeri 3 Singaraja. Uji hipotesis dilakukan dengan teknik analisis uji spearman rank, karena uji prasyarat normalias sebaran data capaian pembelajaran berdistribusi tidak normal dan kinerja siswa berdistribusi normal, sedangkan uji linieritas arah regresi dan uji heterokedastisitas semua data diterima, maka pengujian hipotesis menggunakan uji non parametris yang digunakan untuk menguji kesesuaian antara variabel terikat dan variabel bebas.

Hasil uji spearman rank menunjukkan bahwa nilai korelasi capaian pembelajaran terhadap kinerja siswa bernilai positif sebesar 0,565>0,05 dengan nilai signifikansi $=0,001<0,05$. Nilai signifikan (sig) $<0,05$ yang berarti Ho ditolak dan $\mathrm{Ha}$ diterima, sehingga terdapat hubungan antara capaian pembelajaran teori terhadap kinerja siswa pada saat praktikum dengan tingkat korelasi kuat. Uji spearman rank dilakukan dengan bantuan program SPSS. Hasil uji spearman rank disajikan pada Tabel4.

Tabel 4. Hasil Uji Hipotesis Penelitian Variabel Capaian dan Kinerja

\begin{tabular}{|l|l|r|r|}
\hline \multicolumn{2}{|c|}{} & \multicolumn{1}{|l|}{$\begin{array}{l}\text { Capaian } \\
\text { Pembelajaran }\end{array}$} & $\begin{array}{l}\text { Kinerja } \\
\text { Siswa }\end{array}$ \\
\hline $\begin{array}{l}\text { Capaian } \\
\text { Pembelajaran }\end{array}$ & $\begin{array}{l}\text { Correlation } \\
\text { Coefficient }\end{array}$ & 1.000 & $.565^{* *}$ \\
\cline { 2 - 4 } & Sig. (2-tailed) & .001 \\
\cline { 2 - 4 } & $\mathrm{N}$ & 30 & 30 \\
\hline Kinerja & $\begin{array}{l}\text { Correlation } \\
\text { Coefficient }\end{array}$ & $.565^{* *}$ & 1.000 \\
\cline { 2 - 4 } & Sig. (2-tailed) & .001 & .30 \\
\cline { 2 - 4 } & $\mathrm{N}$ & 30 & 30 \\
\hline
\end{tabular}

Data mengenai hasil belajar teori simulasi digital siswa diambil dengan menggunakan tes hasil belajar (post test). presentasi video diperoleh data sebagai berikut pada Tabel 5 .
Berdasarkan analisis deskriptif terhadap belajar teori simulasi digital pokok bahasan

Tabel 5. Frekuensi Capaian Pembelajaran Teori SIMDIG 


\begin{tabular}{|c|c|c|c|}
\hline \multicolumn{4}{|c|}{ Capaian Pembelajaran } \\
\hline Valid & Frequency & Percent & $\begin{array}{c}\text { Cumulative } \\
\text { Percent }\end{array}$ \\
\hline 26 & 2 & 6.7 & 6.7 \\
\hline 30 & 4 & 13.3 & 20.0 \\
\hline 31 & 1 & 3.3 & 23.3 \\
\hline 32 & 11 & 36.7 & 60.0 \\
\hline 33 & 4 & 13.3 & 73.3 \\
\hline 34 & 5 & 16.7 & 90.0 \\
\hline 35 & 3 & 10.0 & 100.0 \\
\hline Total & 30 & 100.0 & \multicolumn{1}{|c}{} \\
\cline { 1 - 2 } & \multicolumn{3}{|c}{}
\end{tabular}

Tabel 6. Distribusi Frekuensi Skor Capaian Pembelajaran

\begin{tabular}{|c|c|c|l|}
\hline Interval & Frekuensi & Presentase & \multicolumn{1}{|c|}{ Predikat } \\
\hline $29.25-39$ & 28 & $93 \%$ & Sangat Baik \\
\hline $22.75-29.24$ & 2 & $7 \%$ & Baik \\
\hline $16.25-22.74$ & 0 & $0 \%$ & Cukup Baik \\
\hline $9.75-16.24$ & 0 & $0 \%$ & Kurang Baik \\
\hline$\leq 9,74$ & 0 & $0 \%$ & Sangat Kurang Baik \\
\hline Jumlah & 30 & $100 \%$ & \multicolumn{1}{|c|}{} \\
\cline { 1 - 2 } & \multicolumn{2}{|c|}{}
\end{tabular}

Berdasarkan Tabel 6. dapat diketahui dari 30 siswa diperoleh keterangan tingkat capaian pembelajaran teori simulasi digital sebagai berikut: 28 siswa (93\%) memiliki pencapaian pembelajaran sangat baik, 2 siswa (7\%) dengan pencapaian baik, sedangkan tidak ada responden untuk kategori cukup, kurang, dan sangat kurang baik.
Data mengenai kinerja siswa dalam praktikum simulasi digital dengan pokok bahasan presentasi video, diambil dengan menggunakan lembar pengamatan. Berdasarkan analisis deskriptif terhadap kinerja siswa dalam praktikum simulasi digital pokok bahasan presentasi video diperoleh data sebagai berikut pada Tabel 7 .

Tabel 7. Frekuensi Kinerja Siswa Dalam Praktikum SIMDIG

\begin{tabular}{|c|c|c|c|}
\hline \multicolumn{4}{|c|}{ Kinerja Siswa } \\
\hline Valid & Frequency & Percent & $\begin{array}{c}\text { Cumulative } \\
\text { Percent }\end{array}$ \\
\hline 58 & 1 & 3.3 & 3.3 \\
\hline 59 & 1 & 3.3 & 6.7 \\
\hline 60 & 2 & 6.7 & 13.3 \\
\hline 61 & 1 & 3.3 & 16.7 \\
\hline 62 & 1 & 3.3 & 20.0 \\
\hline 63 & 6 & 20.0 & 40.0 \\
\hline 64 & 8 & 26.7 & 66.7 \\
\hline 65 & 1 & 3.3 & 70.0 \\
\hline 66 & 3 & 10.0 & 80.0 \\
\hline 67 & 3 & 10.0 & 90.0 \\
\hline 69 & 3 & 10.0 & 100.0 \\
\hline Total & 30 & 100.0 & \multicolumn{1}{c}{} \\
\cline { 1 - 2 } & \multicolumn{3}{|c}{}
\end{tabular}

Tabel 8. Distribusi Frekuensi Skor Kinerja Siswa 


\begin{tabular}{|c|c|c|l|}
\hline Interval & Frekuensi & Presentase & \multicolumn{1}{|c|}{ Predikat } \\
\hline $58.5-72$ & 29 & 97 & Sangat Baik \\
\hline $49.5-58.4$ & 1 & 3 & Baik \\
\hline $40.5-49.4$ & 0 & 0 & Cukup Baik \\
\hline $31.5-40.4$ & 0 & 0 & Kurang Baik \\
\hline$\leq 31.4$ & 0 & 0 & Sangat Kurang Baik \\
\hline Jumlah & 30 & 100 & \multirow{2}{|c}{} \\
\cline { 1 - 3 } & \multicolumn{3}{|l}{}
\end{tabular}

Berdasarkan Tabel 8. dapat diketahui dari 30 siswa diperoleh keterangan tentang kinerja siswa dalam praktikum simulasi digital sebagai berikut: 29 siswa (97\%) memiliki capaian pembelajaran sangat baik, 1 siswa (3\%) dengan capaian baik, sedangkan tidak ada responden untuk kategori cukup, kurang dan sangat kurang baik.

\section{Pembahasan}

Belajar merupakan suatu proses usaha sadar yang dilakukan individu untuk memperoleh suatu perubahan tingkah laku sebagai umpan balik dari proses pembelajaran. Perubahan perilaku tersebut bukan terjadi hanya pada satu aspek saja, tetapi terjadi secara menyeluruh yang meliputi aspek kognitif, afektif, dan psikomotorik. Kemudian Purwanto mengemukakan bahwa "hasil belajar adalah perubahan tingkah laku yang mencangkup bidang kognitif, afektif, dan psikomotor".
Pada dasarnya kemampuan kognitif merupakan hasil belajar, sebagaimana diketahui bahwa hasil belajar merupakan perpaduan antara faktor pembawaan dan pengaruh lingkungan

Berdasarkan hasil uji analisis menggunakan rumus spearman rank didapat nilai koefisien korelasi sebesar $0,565>0,05$ dengan taraf signifikansi sebesar $0,001<0,05$, maka dapat disimpulkan bahwa terdapat korelasi yang bermakna antara capaian pembelajaran teori simulasi digital terhadap kinerja siswa dalam praktikum simulasi digital program keahlian Teknik Audio Video kelas X di SMK Negeri 3 Singaraja. Dengan $r=0,565$ yang berarti terdapat korelasi kuat dengan arah pola positif. Pola positif menunjukkan bahwa semakin tinggi capaian pembelajaran siswa tentang simulasi digital, maka akan semakin tinggi pula kinerja siswa dalam praktikum simulasi digital.

Tabel 9. Uji Korelasi $X$ dan $Y$

\begin{tabular}{|l|r|r|c|}
\hline$R$ & $\begin{array}{c}R \\
\text { Kuadrat }\end{array}$ & $\begin{array}{c}\text { R Kuadrat } \\
\text { yang } \\
\text { disesuaikan }\end{array}$ & $\begin{array}{c}\text { Standar } \\
\text { Estimasi } \\
\text { Error }\end{array}$ \\
\hline $.565^{\mathrm{a}}$ & .172 & .143 & 2.590 \\
\hline
\end{tabular}

Dari hasil uji hipotesisi terlihat bahwa kontribusi yang diberikan variabel capaian pembelajaran hanya sebesar $17,2 \%$, hal tersebut tentunya dipengaruhi banyak faktor seperti yang dijelaskan dalam Thursan Hakim bahwa keberhasilan belajar dipengaruhi oleh banyak faktor. Agar dapat mencapai keberhasilan belajar yang maksimal, tentu saja kita harus memahami faktor-faktor yang mempengaruhi keberhasilan belajar tersebut. Secara garis besar faktor-faktor yang mempengaruhi keberhasilan belajar itu dapat dibagi menjadi dua bagian besar, yaitu faktor internal dan faktor eksternal. Faktor internal ini berasal dari dalam diri siswa itu sendiri. Faktor internal terdiri dari faktor biologis dan faktor psikologis siswa, sedangkan faktor eksternal bersumber dari luar individu itu sendiri. Faktor eksternal meliputi faktor lingkungan keluarga, faktor lingkungan sekolah, faktor lingkungan masyarakat, dan faktor waktu, maka dapat disimpulkan bahwa keberhasilan belajar seseorang dapat dipengaruhi oleh banyak faktor, jika seseorang siswa sudah memiliki motivasi 
belajar yang tinggi namun disaat bersamaan ada faktor internal maupun eksternal yang mempengaruhi, maka akan dapat menurunkan hasil belajar yang akan diperoleh. Hal tersebut dibuktikan dengan rendahnya kontribusi yang diberikan variabel capaian pembelajaran terhadap kinerja siswa hanya sebesar $17,2 \%$.

Dilihat dari tes capaian pembelajaran kecenderungan nilai tertinggi pada kategori sangat baik dengan prosentase sebesar $93 \%$ serta rata-rata sebesar $82 \%$. Semakin tinggi tingkat motivasi berprestasi seseorang maka akan semakin baik prestasi yang akan diraih. Tingkat motivasi berprestasi siswa yang termasuk dalam kategori sangat baik tersebut menunjukkan adanya dorongan yang tinggi pula dalam diri mereka untuk berprestasi. Siswa yang memiliki kategori di bawah sangat baik keadaan tersebut menunjukkan bahwa ada siswa yang dorongan dalam dirinya untuk berprestasi masih kurang. Kurangnya dorongan untuk berprestasi tersebut dapat dilihat dari kurangnya berorientasi untuk sukses, kurang berpandangan jauh ke depan dan menghargai waktu, kurang bertanggungjawab terhadap tugas, kurang memperhatikan umpan baik, kurang menyukai tantangan, atau tangguh dalam bekerja. Sedangkan dilihat dari kinerja siswa nilai tertinggi pada kategori sangat baik dengan prosentase sebesar $97 \%$ serta ratarata sebesar $89 \%$.

Menurut Slameto, minat merupakan suatu rasa ketertarikan dan kesukaan pada suatu aktivitas. Tingkat minat saat pembelajaran maupun saat praktikum siswa program keahlian Teknik Audio Video tersebut menunjukkan adanya rasa ketertarikan dan kesukaan yang tidak sama pula pada diri mereka untuk mengikuti atau aktif dalam proses belajar mengajar. Ada 2 faktor yang memepengaruhi prestasi belajar seseorang yaitu faktor internal dan eksternal. Faktor internal adalah faktor yang berasal dari dalam diri individu yang sedang belajar seperti jasmani, psikologi, dan kelelahan, sedangkan faktor eksternal adalah faktor yang ada di luar individu seperti faktor keluarga, sekolah, dan masyarakat. Faktor-faktor tersebut menyebabkan siswa mempunyai tingkat pencapaian pembelajaran yang beragam.
Pada kondisi seperti ini siswa yang belum mencangkup nilai cukup di prediksikan dapat mengalami kesulitan pada tingkat selanjutnya. Pencapaian pembelajaran kognitif siswa pada materi pokok presentasi video merupakan pencapaian dasar untuk mengenal suatu teknologi pada kamera. Hasil suatu pembelajaran dapat dilihat dari pencapaian hasil belajar siswa. Apabila dilihat kenyataan yang ada dalam sistem pendidikan yang diselenggrakan, pada umumnya baru menerapkan beberapa aspek kognitif tingkat rendah, seperti pengetahuan, pemahaman dan sedikit penerapan, sedangkan tingkat analisis, sintetis dan evaluasi jarang sekali diterapkan. Apabila semua tingkat kognitif diterapkan secara merata dan terusmenerus maka hasil pendidikan akan lebih baik serta menghasilkan kinerja yang baik.

Tujuan aspek kognitif berorientasi pada kemampuan berfikir yang mencangkup kemampuan intelektual yang lebih sederhana, yaitu mengingat, sampai pada kemampuan memecahkan masalah yang menuntut siswa untuk menghubungkan dan menggabungkan beberapa ide, gagasan, metode atau prosedur yang dipelajari untuk memecahkan masalah tersebut. Menyikapi hasil penelitian maka sebaiknya guru memberikan remidial kepada siswa untuk mencapai ketuntasan belajar dalam teori simulasi digital sedangkan dari pihak sekolah dalam pemenuhan fasilitas terutama hal komputer dan kamera yng merupakan komponen utama untuk melakukan praktikum, hendaknya lebih diperhatikan dalam pembelajaran siswa untuk mengetahui, serta menumbuhkan tingkat pencapaian pembelajaran teori simulasi digital dalam ranah kognitif.

\section{SIMPULAN DAN SARAN Simpulan}

Berdasarkan hasil penelitian dan pembahasaan dapat ditarik simpulan hasil penelitian sebagai berikut.

1. Terdapat hubungan antara pencapaian pembelajaran teori simulasi digital terhadap kinerja siswa dalam praktikum simulasi digital pada program keahlian Teknik Audio Video kelas $X$ di SMK Negeri 3 Singaraja dengan diperoleh koefisien korelasi sebesar 0,565>0,05 
dengan nilai signifikansi sebesar $0,001<0,05$ yang artinya arah korelasi positif dengan tingkat korelasi kuat.

2. Pencapaian pembelajaran teori simulasi digital dalam pokok bahasan presentasi video kelas X di SMK Negeri 3 Singaraja diperoleh rata-rata kelas sebesar $82 \%$ dalam kategori baik.

3. Tingkat kinerja siswa saat praktikum simulasi digital dalam pokok bahasan presentasi video kelas $X$ di SMK Negeri 3 Singaraja diperoleh rata-rata kelas sebesar $89 \%$ dalam kategori baik.

\section{Saran}

Berdasarkan hasil penelitian yang telah dilakukan maka saran yang dapat diberikan peneliti kepada peneliti lainnya untuk menginvestigasikan beberapa faktor lain yang kemungkinan mampu mempengaruhi kedua variabel tersebut. Dengan dapat juga membuatkan angket untuk mengetahui lebih dalam tentang motivasi siswanya. Dengan adanya penelitian tersebut maka akan tersedia masukan yang komprehensif mengenai faktor yang mempengaruhi kedua variabel tersebut. Selain hal tersebut diharapkan juga nantinya agar penelitian ini biasa dilakukan di ruang lingkup yang lebih luas lagi untuk memaksimalkan hasil dari hubungan atau pengaruh yang diberikan oleh masingmasing variabel.

\section{DAFTAR PUSTAKA}

Dimas, Setiawan. (2012). Definisi Kinerja. Diambil kembali dari http://definisimu.blogspot.co.id

Majid, A. (2006). Perencanaan Pembelajaran Mengembangkan Standar Kompetensi Guru. Bandung: Remaja Rosdakarya.

RISTEKDIKTI. (2015). Paradigma Capaian Pembelajaran. Dokumen 005.

Setyono, Budi. (2005). Jurnal Pengembangan Pendidikan "Penilaian Otentik dalam Kurikulum Berbasis Kompetensi". Lembaga Pembinaan dan Pengembangan Pendidikan Universitas Jember. 